\title{
Sistem Pendukung Keputusan dalam Menentukan Kelayakan Lokasi Tower pada PT. Winer Medan dengan Menggunakan Metode Weight Product
}

\author{
Guntur Syahputra, Milfa Yetri, Yohanni Syahra \\ STMIK Triguna Dharma
}

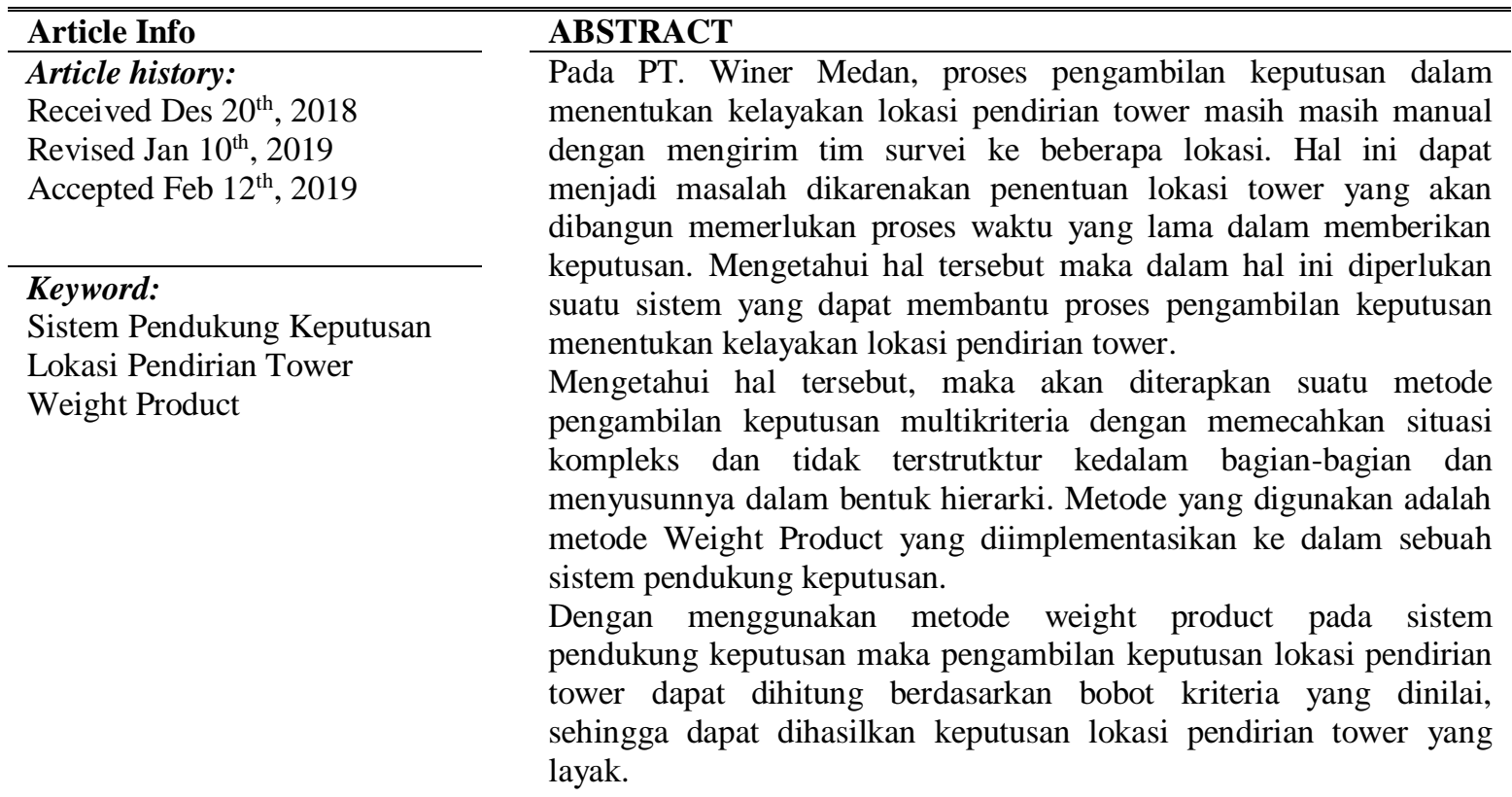

\section{PENDAHULUAN}

Perkembangan kebutuhan telekomunikasi dan informasi yang semakin cepat dewasa ini, telah mendorong pihak operator penyedia jaringan komunikasi untuk selalu berkembang, operator dituntut agar dapat menyediakan jangkauan sinyal yang luas dan juga kekuatan sinyal jaringan yang mumpuni. Keberadaan tower BTS (Base Transceiver Station) menjadi sangat penting dalam melayani setiap aktivitas dari masyarakat dalam kebutuhan berkomunikasi. Pihak operator harus dapat menentukan lokasi tower BTS yang potensial agar semua wilayah dapat terjangkau sinyalnya.

Penentuan lokasi tower BTS (Base Transceiver Station) menjadi masalah yang sering dihadapi pihak kontraktor, seperti pada PT. Winer. Pemilihan lokasi tower baru merupakan permintaan pihak operator terhadap suatu daerah yang potensial agar terjangkaunya semua pelanggan maupun sekedar untuk menambah kekuatan sinyal jaringan di wilayah tersebut. Mekanisme penentuan kelayakan lokasi tower pada PT. Winer masih manual dengan mengirim tim survei ke beberapa lokasi sekitar daerah rencana pembangunan tower baru, setelah diketahui keadaan di lapangan sehingga dapat ditentukan prioritas lokasi-lokasi yang ada. Hal ini dapat menjadi masalah dikarenakan penentuan lokasi tower yang akan dibangun kurang akurat dan memerlukan proses waktu yang lama dalam memberikan keputusan. Salah satu solusi untuk penentuan lokasi Pembangunan tower ialah menerapkan pada sebuah sistem dengan metode Weight Product. Metode Weight Product merupakan salah satu metode dalam sistem pendukung keputusan yang menggunakan perkalian untuk menghubungkan rating atribut.

Sistem Pendukung Keputusan memungkinkan sebuah keputusan dapat dihasilkan secara akurat dan cepat, dalam hal ini memberikan keputusan kelayakan lokasi pembangunan tower baru pada PT. Winer. 


\section{LANDASAN TEORI}

\subsection{Pembangunan Tower}

Fenomena semakin banyaknya menara telekomunikasi menimbulkan kesan bahwa kemajuan teknologi sangat berpengaruh terhadap tata kota bagi kehidupan masyarakat. Fungsi BTS operator seluler adalah untuk mengirimkan dan menerima sinyal radio dari dan ke perangkat telepon seluler. BTS atau Base Transceiver Station merupakan perangkat penting bagi jaringan komunikasi. BTS adalah elemen dalam jaringan seluler atau Cell Network. Elemen ini berperan untuk memfasilitasi dan mengkoneksikan perangkat komunikasi nirkabel dengan jaringan operator. Sebagai penyedia jaringan operator seluler dengan jangkauan terluas, BTS Tower Telkomsel memiliki jumlah terbanyak di antara BTS Tower operator seluler lainnya. Dengan demikian pengertian tower BTS ini adalah menara atau tower yang difungsikan sebagai base transceiver station untuk komunikasi nirkabel.

Berdasarkan definisi tower BTS dapat dikatakan peran BTS telekomunikasi sangat penting. Sebagai pemancar dan penerima sinyal keberadaannya adalah suatu hal wajib. Jika berada di lokasi yang jauh dari BTS maka sinyal yang diterima mobile station atau telepon seluler akan semakin lemah. Akibatnya sering terjadi gangguan seperti sinyal putus nyambung, blank spot, no signal, baterai menjadi cepat lemah atau habis karena terlalu sering dalam kondisi pencarian sinyal, telepon mudah putus dan gangguan lainnya.. Mengenai contoh penerapan pasal dalam Peraturan Bersama Menteri ini dapat disimak dalam artikel Pertanggungjawaban Hukum Jika Menara BTS Roboh. Selanjutnya fokus pada pengaturan dalam Permenkominfo 02/2008. Menurut Pasal 1 angka 3 Permenkominfo 02/2008, menara adalah bangunan khusus yang berfungsi sebagai sarana penunjang untuk menempatkan peralatan telekomunikasi yang desain atau bentuk konstruksinya disesuaikan dengan keperluan penyelenggaraan telekomunikasi. Sedangkan menara bersama menurut Pasal 1 dan angka 4 Permenkominfo 02/2008 adalah menara telekomunikasi yang digunakan secara bersama-sama oleh Penyelenggara Telekomunikasi

\subsection{Sistem Pendukung Keputusan}

Decision Support System atau Sistem Pendukung Keputusan yang selanjutnya kita singkat dalam skripsi ini menjadi SPK, secara umum didefinisikan sebagai sebuah sistem yang mampu memberikan kemampuan baik kemampuan pemecahan masalah maupun kemampuan pemgkomunikasian untuk masalah semi-terstruktur. Secara khusus, SPK didefinisikansecara khusus SPK Menurut Hermawan(2005:12)Sistem Pendukung Keputusan adalah sebagai sebuah sistem yang mendukung kerja seorang manajer maupun sekelompok manajer dalam memecahkan masalah semi-terstuktur dengan cara memberikan informasi ataupun usulan menuju pada keputusan tertentu.

\subsection{Weight Product}

Metode Weighted Product merupakan metode dengan menggunakan perkalian untuk menghubungkan rating atribut, dimana rating setiap atribut harus dipangkatkan dengan bobot atribut yang bersangkutan. Metode Weighted Product (WP) merupakan salah satu metode penyelesaian yang ditawarkan untuk menyelesaikan masalah Multi Atribute Decission Making (MADM). Metode Weighted Product (WP) mirip dengan metode Weighted Sum (WS), hanya saja Weighted Product, terdapat perkalian dalam perhitungan matematikanya. Metode Weighted Product juga disebut analisis berdimensi karena struktur matematikanya menghilangkan satuan ukuran. Metode Weighted Product sering dikenal juga dengan istilah metode perkalian terbobot. Konsep dasar metode Weighted Product adalah mencari perkalian terbobot dari rating kinerja pada setiap alternatif pada semua atribut. Proses ini sama halnya dengan proses normalisasi. Tahapan tahapan metode Weighted Product :

1. Penentuan kriteria pemilihan

2. Penilaian bobot kepentingan tiap kriteria

3. Penentuan range nilai tiap kriteria

4. Penilaian tiap alternatif menggunakan semua atribut dengan penentuan range nilai yang disediakan yang menunjukan seberapa besar kepentingan antar kriteria.

5. Dari data penilaian tiap bobot atribut dan nilai alternatif dibuat matrik keputusan $(\mathrm{X})$.

6. Dilakukan proses perbaikan/normalisasi bobot kriteria (W)

Keterangan :

$$
W j=\frac{W j}{\sum W j}
$$

$\mathrm{Wj}=$ Bobot Atribut 
$\Sigma \mathrm{Wj}=$ Penjumlahan Bobot Atribut

7. Dilakukan proses normalisasi (S) matrik keputusan dengan cara mengalikan rating atribut, dimana rating atribut terlebih dahulu harus dipangkatkan dengan bobot atribut.

Atribut Keuntungan : pangkat bernilai positif

Atribut Biaya : pangkat bernilai negatif

$$
S i=\prod_{j=1}^{n} X i j^{w j}
$$

((Sumber : Jurnal Kependidikan, Volum 44, no 2, Nov 2014, Hal 139-145)

Keterangan :

$\mathrm{Si}=$ Hasil Normalisasi Matriks

$\mathrm{Xij}=$ Rating Alternatif Per Atribut

$\mathrm{Wj}=$ Bobot Atribut

$\mathrm{i}=$ Alternatif

$\mathrm{j}=$ Atribut

8. Proses preferensi untuk tiap alternatif (V)

$$
V i=\frac{\prod_{j=1}^{n} X i j^{W i}}{\prod_{j=1}^{n}\left(X j^{*}\right)^{W i}}
$$

Keterangan :

$\mathrm{Vi}=$ Hasil prefrensi alternatif ke-i

$\mathrm{Xij}=$ Rating alternatif per atribut

$\mathrm{Wj}=$ Bobot atribut

$\mathrm{i}=$ alternatif

$\mathrm{j}=$ atribut

\section{PEMBAHASAN DAN HASIL}

Dalam merancang Sistem Pendukung Keputusan penentuan lokasi terbaik untuk pembangunan tower pada PT. Winer ditentukan beberapa kriteria dan bobotnya yaitu:

Tabel .1 Kriteria Penilaian

\begin{tabular}{|c|l|c|}
\hline Inisial & \multicolumn{1}{|c|}{ Kriteria Penilaian } & Bobot \\
\hline C1 & Jumlah Kepadatan Pendudukan & 5 \\
\hline C2 & Legalitas Lahan & 3 \\
\hline C3 & Biaya & 4 \\
\hline C4 & Topografi & 4 \\
\hline
\end{tabular}

Tabel .2 Lokasi

\begin{tabular}{|c|c|}
\hline Kode Lokasi & Nama \\
\hline A1 & Bandar Huluan \\
\hline A2 & Bosar Maligas \\
\hline A3 & Gunung Malela \\
\hline A4 & Pematang Bandar \\
\hline A5 & Jawa Maraja Bah jambi \\
\hline A6 & Huta Bayu Raja \\
\hline
\end{tabular}




\begin{tabular}{|l|l|}
\hline A7 & Raya Kahean \\
\hline A8 & Silou Kahean \\
\hline
\end{tabular}

Rating kecocokan setiap alternatif pada setiap kriteria dinilai dengan satu sampai 5, yaitu:

Tabel .3 Bobot Untuk Penilaian

\begin{tabular}{|c|c|}
\hline Penilaian & Bobot \\
\hline Sangat Baik & 5 \\
\hline Baik & 4 \\
\hline Cukup & 3 \\
\hline Buruk & 2 \\
\hline Sangat Buruk & 1 \\
\hline
\end{tabular}

Setelah ditentukan parameter bobot untuk nilai setiap kriteria pada setiap lokasi yang dinilai, selanjutnya ialah mengkonversi data yang didapat dari lapangan kedalam nilai bobot yang telah ditentukan.

\begin{tabular}{|c|c|c|c|c|}
\hline No Urut & Lokasi & Vektor S & Vektor V & Keputusan \\
\hline 1 & Pematang Bandar & 3,9913 & 0,2117 & Terpilih \\
\hline 2 & Bandar Haluan & 3,1302 & 0,1660 & - \\
\hline 3 & Huta Bayu Raja & 2,9907 & 0,1586 & - \\
\hline 4 & Jawa Maraja Bahjambi & 2,3784 & 0,1262 & - \\
\hline 5 & Gunung Malela & 2,1739 & 0,1153 & - \\
\hline 6 & Bosar Maligas & 1,4987 & 0,0795 & - \\
\hline 7 & Raya Kahean & 1,4612 & 0,0775 & - \\
\hline 8 & Silou Kahean & 1,2287 & 0,0625 & - \\
\hline
\end{tabular}

Maka dari perhitungan diatas dapat diperoleh lokasi terbaik untuk pembangunan tower ialah Alternatif (A4)

Lokasi Pematang Bandar yang memiliki nilai prioritas tertinggi dengan nilai 0,2117

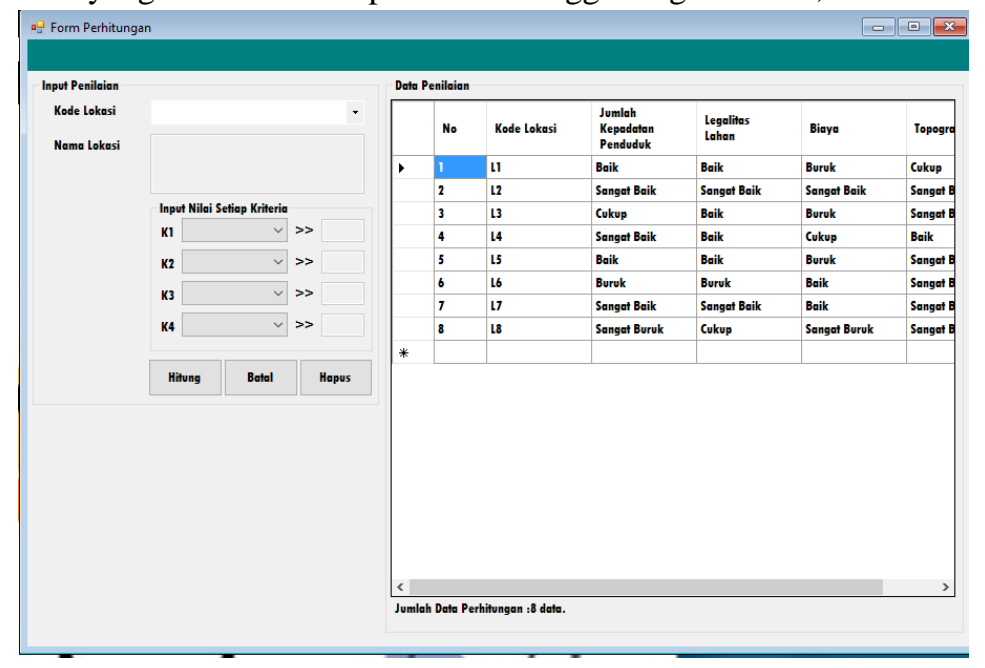

Gambar 1 Form Penilain Lokasi 


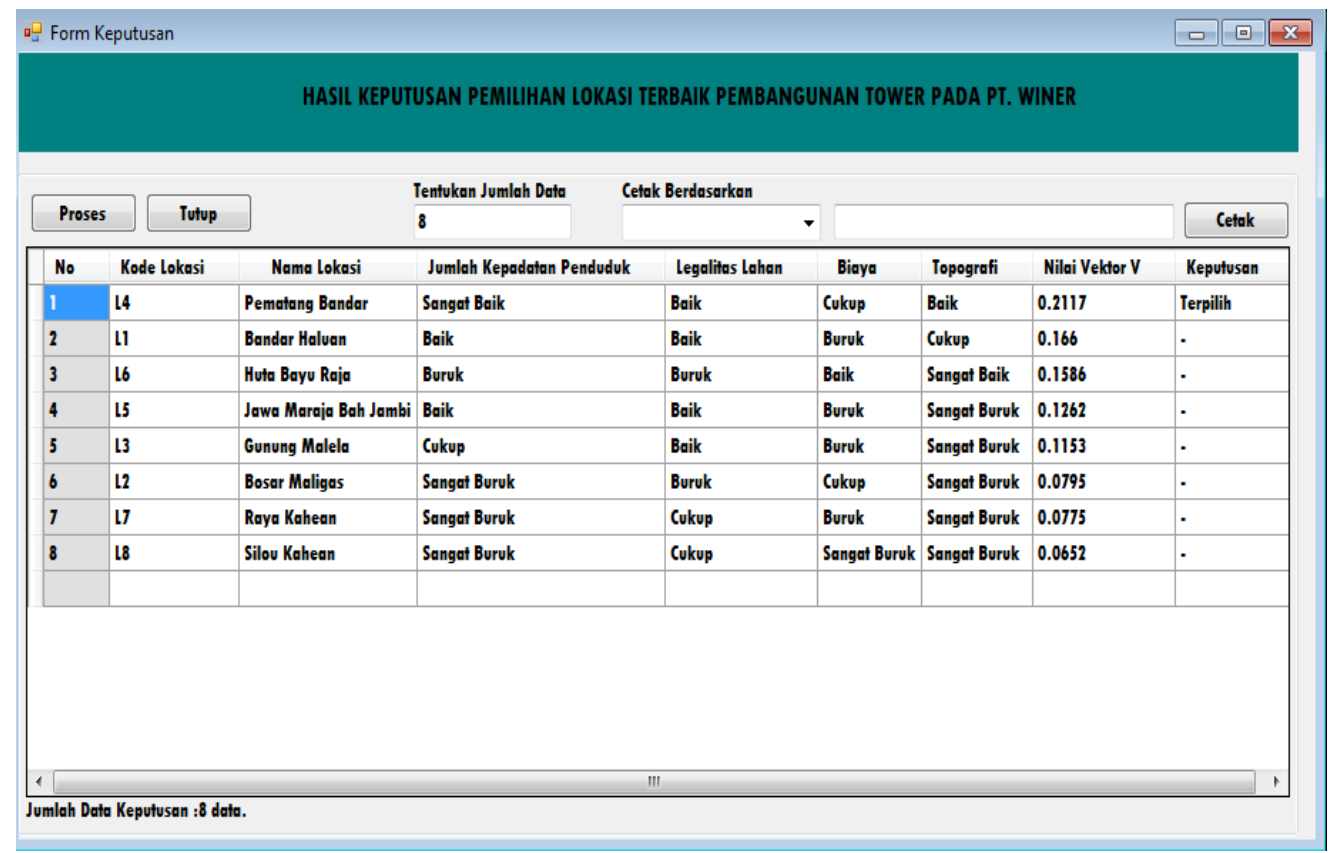

Gambar 2 Form Keputusan

\section{KESIMPULAN}

Berdasarkan analisa pada permasalahan yang terjadi dalam kasus yang diangkat, maka dapat ditarik kesimpulan yaitu :

1. Dalam penerapan metode Weighted Product dilakukan dengan beberapa tahap, yaitu : melakukan perbaikan bobot, menghitung vektor $\mathrm{S}$, dan menghitung vektor $\mathrm{V}$ yang telah dibahas di bagian pembahasan sebelumnya.

2. Dalam memulai proses pembuatan sistem terlebih dahulu melakukan perancangan sistem yang akan dibuat. Sehingga berhasil merancang suatu sistem pendukung keputusan untuk menentukan kelayakan lokasi pendirian tower.

3. Sistem pendukung keputusan pemilihan lokasi tower pada PT. Winer telah berhasil dibuat dengan penerapan metode Weighted Product pada salah satu bahasa pemograman yaitu program Visual Studio 2008, dengan menggunakan database Access dan menampilkan laporan dengan Crystal Report.

\section{REFERENSI}

[1] Kusrini. 2007. Konsep Dan Aplikasi Sistem Pendukung Keputusan. Yogyakarta: Penerbit Andi

[2] Rosa, A.S., \& Shalahuddin, M. 2013. Rekayasa Perangkat Lunak Terstruktur dan

[3] Berorientasi Objek. Bandung : Informatika.

[4] Priyanto, R. 2009. Langsung Bisa Visual Basic.NET 2008. Yogyakarta: Penerbit ANDI.

[5] Jogiyanto. 2005. Analisis Dan Desain Sistem Informasi. Yogyakarta: Penerbit ANDI.

[6] Fartindyyah, N dan Subiyanto. 2014. Sistem pendukung keputusan peminatan SMA menggunakan Weighted Product (WP). Jurnal Kependidikan, 44(2), 139-145. 